\title{
Investigations of sintering temperature and cell viability of biocompatible nano Yttria stabilised zirconia coated on 316L SS for dental applications
}

DOI:10.36909/jer.ICMMM.12435

\author{
S.Mohandoss $^{1 *}$, S.P.Srinivasan ${ }^{2}$ \\ ${ }^{1 *}$ Department of Chemistry, Rajalakshmi Engineering College, Chennai 602105 \\ ${ }^{2}$ Department of Mechanical Engineering Rajalakshmi Engineering College, Chennai 602105 \\ Email ID : mohandoss.s@rajalakshmi.edu.in Corresponding Author.
}

\begin{abstract}
Development of biocompatible dental implants has become significant impact in dental industry. In the present work, we report for the development of biocompatible nano Yttria stabilised Zirconia (YSZ) coatings on 316L stainless steel (316L SS) obtained by EPD process. The optimized sample (nano YSZ coating on 316 obtained at applied potential of $70 \mathrm{~V}$ for 5 minutes) were sintered in air at 600,800 and $900^{\circ} \mathrm{C}$. The surface morphology and composition of the coatings were characterized by XRD and FE-SEM with EDAX. The electrochemical performance of the uncoated metal and nano YSZ coated 316L SS samples were evaluated in artificial saliva (AS) medium using electrochemical techniques such as Open Circuit Potential - time measurement (OCP), Electrochemical Impedance Spectroscopy (EIS) and Cyclic Potentiodynamic Polarization (CPP).
\end{abstract}

Keywords: YSZ, 316L SS,EPD, Artificial saliva, Electrochemical studies.

\section{INTRODUCTION}

Corrosion of dental implant in oral environment is one of the major concerns as it aggravates the local environment leading to failure of dental implants.Corrosion occurs due to various acidic and basic $\mathrm{pH}$ fluctuations encountered in the mouth through the different food stuffs we consume, 
presence of debris material in the oral environment after eating (G. Duffo et al.,1999, T.P. Chaturvedi et al., 2009 \& J. Mouhyi et al., 2012) The rate of corrosion increases when we chew food under different conditions due to the regular mechanical forces of the mouth. During this process, large amount of metal ions and debris are generated which could lead to accumulation in the gums and finally to adverse tissue reactions in the oral environment (C.Danieli et al., 2013 \& A. Mombelli et al., 2018). Under low pH, implant surface gets easily corroded due torelease of more ions. Increased porosity, reduced marginal integrity and loss of strength in the implant surface leads to excessive corrosion.In acidic medium, the active dissolution of metal ions can occur upon exposure of the bulk metal (K.J. Anusavice et al., 2003). Hence, there is a necessity to improve the surface of implants by using surface modification technologies.

In most of the biomedical industry, medical grade 316L Stainless steel (SS) alloys are used most often (J.C. Watahaet al., 1996). This SS alloy leads to pitting corrosion most likely in the oral environment. Hence, utmost care is required to maintain and use passive (oxide) surface conditions. The use of 316L SS often results in allergy for patients, thus bringing about a need for surface modification or new lookout for an alternative material (A. Wennerberg et al., 2010).

Compared to stainless steel, bioinert ceramics such as Zirconia and alumina have a higher compressive strength and superior biocompatibility. $\alpha$-alumina with hexagonal crystals is responsible for its chemically stability which may be due to crystallographic stability (Maria Cecilia Corrêa de Sá e Benevides de Moraesa et al., 2004).Usually, Zirconia ceramic is not stable as itoccurs in three crystallographic phases such as cubic, tetragonal, monoclinic phase and thesechanges may take place under various conditions (change of temperature, humidity and mechanical stress) (I. Denry et al., 2008 \& Chevalier et al., 2009). 
Zirconia and YSZ possess high biocompatibility, chemical resistance and mechanical properties such as high toughness, high flexural strength, wear resistance and corrosion resistance (D.Liu et al., 2012 \& Ossama Saleh Abd El-Ghany et al.,2016). They are chemically inert materials that allowgood cell adhesion compared to other dental ceramics (Abhishek Apratim et al.,2015). Additionally, Zirconia exhibits several promising physical and mechanical properties including low thermal conductivity, high flexural strength (9001,200 MPa), favourable fracture resistance, as well as wear and corrosion resistance. Zirconia possesses excellent properties due to a phenomenon termed as phase transformation toughening (Norbert Cionca et al.,2017 \& V.Muthukumaran et al.,2010)

Electrophoretic Deposition process is suitable method for deposition of nano YSZ on the surface of metal substrate (316L SS). EPD instrumentation requires simple components like DC power source meter and glass beaker with mechanical stirring. EPD process provides highly uniform and crack free coating from various suspensions of bioceramics in organic solvents (Emilija Bajraktarova-Valjakova et al.,2018). The deposition rate can be controlled by varying applied voltage and coating time.

\section{MATERIALS AND METHODS}

Nano YSZ (99.99\%) (Particle size <100nm) obtained from Saint Gobain, China. All other chemicals and solvents used in the following experiments were of analytical grade.

\subsection{EXPERIMENTAL}

\subsubsection{SUSPENSION PREPARATION}

To prepare 2\% nano YSZ suspension, the nano YSZ powder was finely grounded in mortar and pestle. The accurately weighed 1 gram of nano YSZ was mixed with $100 \mathrm{ml}$ of isopropyl alcohol in a $100 \mathrm{ml}$ beaker. The obtained suspension was placed in ultrasonicator for $10 \mathrm{~min}$ to 
get agglomerate free suspension. The $1.0 \mathrm{~cm}^{2} 316 \mathrm{~L}$ SS were used as cathode and 314 stainless steel as anode.

\subsubsection{NANO YSZ DEPOSITION ON METAL SUBSTRATE BY EPD PROCESS}

316L SS specimens were encapsulated in Teflon and electrodes were totally immersed in $2 \%$ nano YSZ suspension so that only the uncovered substrate face in front of the anode can be coated. A magnetic stirrer was used in order to avoid particle sedimentation. A power source was used to apply the desired current density to the suspension for a fixed time. The coatings were deposited from 30 to $120 \mathrm{~V}$ to study the effect of deposition at a constant time of $5 \mathrm{~min}$. The nano YSZ coated 316L SS samples are removed from the bath and dried at room temperature and then the dried samples were sintered at 600,800 and $900^{\circ} \mathrm{C}$.

\subsection{CHARACTERIZATION}

TheMicro hardness tests have been performed using a Vickers microindentor.The microstructure and uniform deposits of nano YSZ were observed by FESEM (CARL ZEIS). XRD for nano YSZ were obtained using Bruker model. The Electrochemical impedance spectroscopic investigations were evaluated using electrochemical workstation (Bio Logic SP240).

\section{RESULTS AND DISCUSSION}

\subsection{MICRO HARDNESS STUDIES}

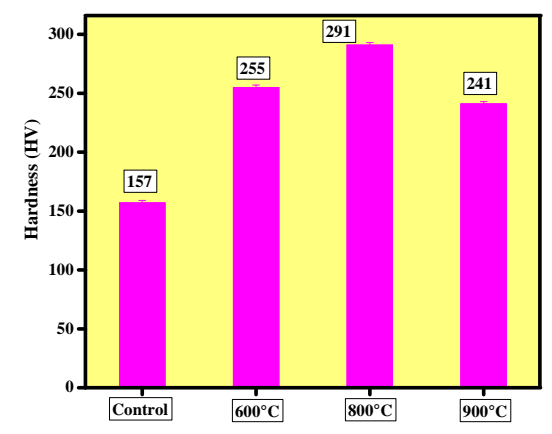


Figure 1 Micro hardnessprofile obtained for uncoated 316L SS and nano YSZ coated on 316L SS samples sintered in air at different temperature of $600^{\circ} \mathrm{C}, 800^{\circ} \mathrm{C}$ and $900^{\circ} \mathrm{C}$.

Figure $1(\mathrm{a} \& \mathrm{~b})$ shows Micro hardness profile obtained for bare 316L SS and nano YSZ coated 316L SS specimens. Micro hardness tests for the optimized nano YSZ coated 316L SS samples have been performed using a Vickers microindentor with loads of $100 \mathrm{~g}$ and load time of5 seconds ( I.Corni et al.,2008 \& Brandusa Ghiban et al., 2006). The optimised sample sintered at $800^{\circ} \mathrm{C}$ possess high hardness compared to other sintering temperatures.

\subsection{XRD STUDIES}

The XRD patterns of nano YSZ deposits on 316L SS sintered in air at different temperature $600^{\circ} \mathrm{C}, 800^{\circ} \mathrm{C}$ and $900^{\circ} \mathrm{C}$ respectivelywere shown in Figure2. All the indexed peaks match well with standard JCPDS card No. 82-1246 indicating the presence of cubic structure (T. Sopcak et al., 2018). The crystallite size was determine using Scherrer's formula and the size for nano YSZ coated 316L SS was found to be $31 \mathrm{~nm}$. Further, it can be observed that there are no additional peaks related to metal oxides and the nano YSZ deposits.

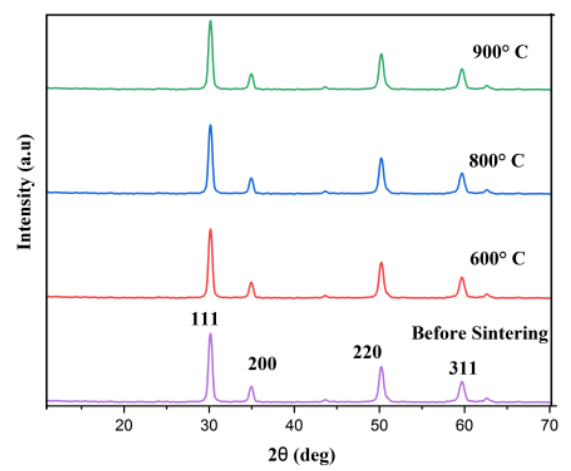

Figure 2 X-ray diffraction of nano YSZ coated on 316L SS samplesintered in air at different temperature of $600^{\circ} \mathrm{C}, 800^{\circ} \mathrm{C}$ and $900^{\circ} \mathrm{C}$ respectively. 


\subsection{FESEM WITH EDAX ANALYSIS}

FESEM and EDAX analysis were carried out to study the morphology, size and elemental composition of nano YSZ deposits on 316L SS sintered in air at 600,800 and $900^{\circ} \mathrm{C}$ respectively.The obtained FESEM and EDAX results were presented in Figure $3 \& 4$. It was observed that nano YSZ coated sample sintered at $800^{\circ} \mathrm{Cpossess}$ uniform grain size distribution with close packed arrangement of particles. Also, porosity is important for the integration of dental implants with bone tissue (G. Callon et al., 2000 \& M. Mour et al., 2010). The nano porous nature obtained from the FESEM image indicate the possible application of nano YSZ coated 316L SS in load bearing areas. Further, there were no traces of metal oxide peaks for base metal stainless steel.

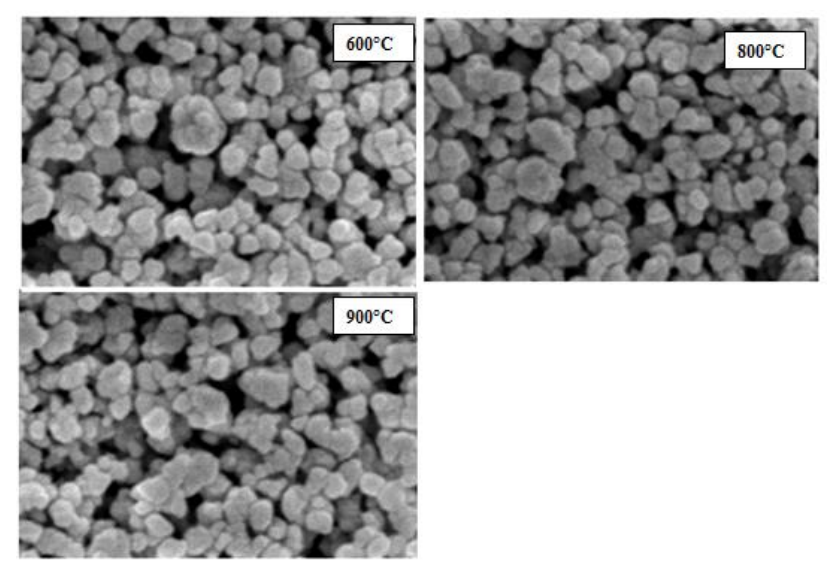

Figure 3 FESEM image obtained for nano YSZ coated on 316L SS sintered in air at $600^{\circ} \mathrm{C}, 800^{\circ} \mathrm{C}$ and $900^{\circ} \mathrm{C}$ respectively.

Additionally, EDAX analysis represented in Figure4 confirms the presence of yttrium stabilized nano YSZ along with the oxygen peak. This further confirms the absence of oxidized products of the base metal and decomposition of nano YSZ and formation of new products on the surface. 


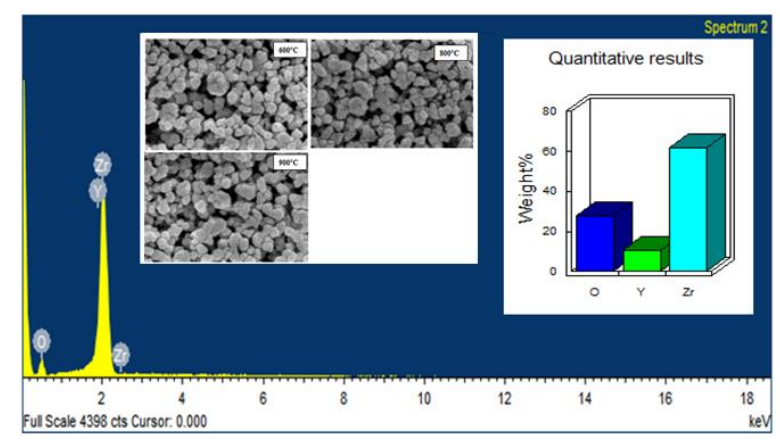

Figure 4 EDAX obtained for nano YSZ coated on 316L SS, sintered in air at different temperature of $600^{\circ} \mathrm{C}, 800^{\circ} \mathrm{C}$ and $900^{\circ} \mathrm{C}$ respectively.

\subsection{OPEN CIRCUIT POTENTIAL TIME MEASUREMENT}

Figure 5 depicts the OCP-time measurements values of nanoYSZcoated 316L SS sintered at different temperature $\left(600,800\right.$, and $\left.900^{\circ} \mathrm{C}\right)$. The OCP values are directly shifted towards active direction after 1 hour and it attains steady state soon. The OCP of nano YSZ coated samples shifts towards nobler direction when compared to uncoated 316L SS. It must be noted carefully that samples sintered at $800^{\circ} \mathrm{C}$ in air shift more nobler direction when compared to the samples sintered at 600 and $900^{\circ} \mathrm{C}$ respectively. This indicates that samples sintered in air at $800^{\circ} \mathrm{Csignificantly} \mathrm{enhance} \mathrm{corrosion} \mathrm{resistant} \mathrm{properties} \mathrm{of} \mathrm{the} \mathrm{metal}$ surfacedue to the packing of nano YSZ firmly on 316L SS (Young-Ah Yi et al., 2015). While the samples sintered at 600 and $900^{\circ} \mathrm{C}$, nano YSZ particles were not tightly held together. Thus, $800^{\circ} \mathrm{Cwas}$ observed to be the optimized sintering temperature for nano YSZ on 316L SS. 


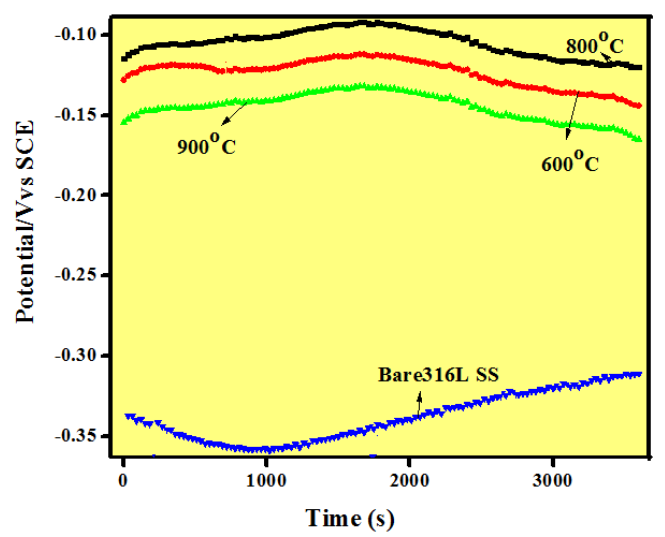

Figure 5 OCP results obtained for optimized (70 V \& 5 minutes) nano YSZ coated 316L SS at different sintering temperature in air.

\subsection{ELECTROCHEMICAL IMPEDANCE STUDIES}

Figure6indicates EIS values of nano YSZ coated 316L SS sintered at different temperature $\left(600,800\right.$ and $\left.900^{\circ} \mathrm{C}\right)$. The frequency sweep was performed from $10 \mathrm{kHz}$ down to $10 \mathrm{mHz}$ with a perturbation amplitude of $10 \mathrm{mV}$. The coated samples obtained at $70 \mathrm{~V}$ and 5 minutes sintered at $800^{\circ} \mathrm{C}$ possess high impedance $\left(245744 \mathrm{Ohm}^{2}\right.$ ) when compared to other samples indicating high corrosion resistance. The obtained Nyquist impedance values of all the specimens were fitted usingZfit software fitting analysis (Florence Barre, et al., 2003 \& Xiaoqiang Xue et al., 2017).. Based on the simulated values, the equivalent circuit is proposed and depicted in Figure 6, where, Rs-solution resistance, passivation resistances and impedance values were high in optimized $800^{\circ} \mathrm{C}$ sintering temperature. These studies confirm that nano-YSZ coated 316L SS possess more resistivity of ions attack from AS (abbreviate somewhere) medium as it consistently resist the electron transfer from metal surface to the bulk of the AS medium. 


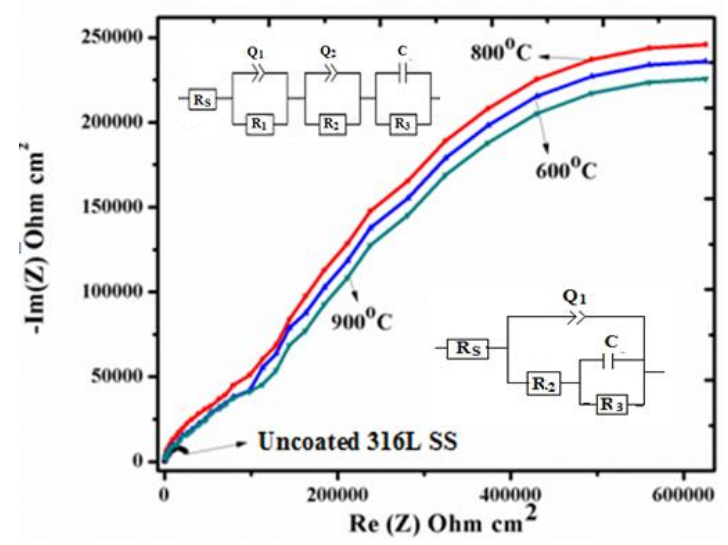

Figure 6 Nyquist impedance for optimized nano YSZ coated 316L SS at different sintering temperatures in air.

Bode impedance and Bode phase plots were given in the Figure 7 (a\&b). The samples sintered at $800^{\circ} \mathrm{C}$ possess maximum impedance value compared to other sintering temperature and uncoated specimens (Sharif Hussein Sharif Zein et al., 2012). The phase angle of the optimized nano YSZ coated $316 \mathrm{~L} \mathrm{SS}$ sintered at $800^{\circ} \mathrm{C}$ exhibited a significant shift to $-70^{\circ}$ indicating high capacitive behaviour. This data revealed that the corrosion resistivity of optimized nano YSZ coated $316 \mathrm{~L} \mathrm{SS}$ sintered at $800^{\circ} \mathrm{C}$ in air is significantly higher compared to other sintering temperature.
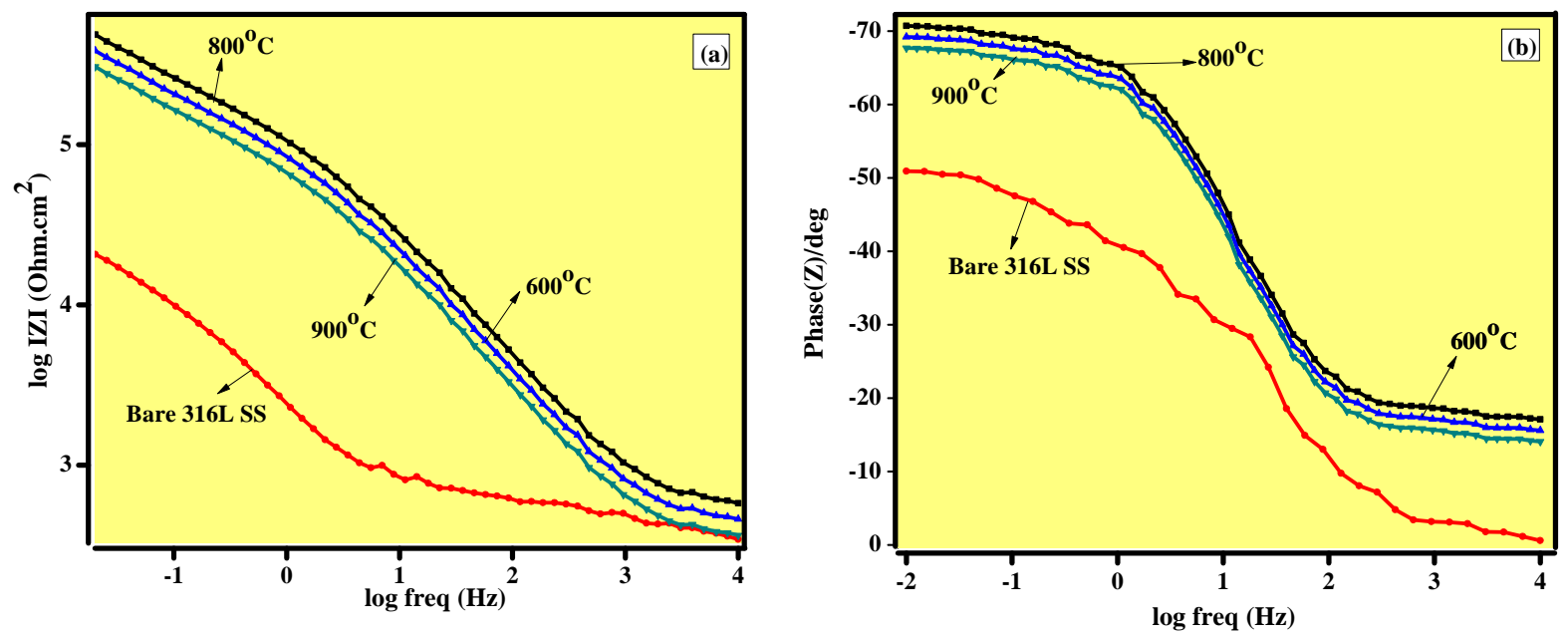
Figure 7 (a) Bode impedance and (b) Bode phase plots obtained for optimized nanoYSZ coated 316L SS sintered in air at different sintering temperature.

Table $1 \mathrm{Z}$ fit values of nano YSZ coated (sintered at 600,800 and $900^{\circ} \mathrm{C}$ under air atmosphere) samples under AS in medium comparison with uncoated 316L SS.

\begin{tabular}{|c|c|c|c|c|c|c|c|c|c|c|}
\hline $\begin{array}{c}\text { Sintering } \\
\text { Temperature }\end{array}$ & $\begin{array}{c}|\mathrm{Z}| \\
\Omega \mathrm{cm}^{2}\end{array} \mid$ & $\begin{array}{c}\mathbf{R}_{\mathrm{S}} \\
\Omega \mathrm{cm}^{2}\end{array}$ & $\begin{array}{c}Q_{\text {coat }} \\
\left(\mathrm{F} \mathrm{cm}^{-2} \mathbf{s}^{\mathbf{n}}\right)\end{array}$ & $\mathbf{n}_{\text {coat }}$ & $\begin{array}{c}\mathbf{R}_{1} \\
\text { YSZ coat }\end{array}$ & $\begin{array}{c}Q_{b} \\
\left(F \mathbf{c m}^{-2} \mathbf{s}^{n}\right)\end{array}$ & $\mathbf{n}_{\mathbf{b}}$ & $\begin{array}{c}\mathbf{R}_{2} \\
\Omega \mathrm{cm}^{2}\end{array}$ & $\begin{array}{c}\mathrm{C}_{\mathrm{dl}} \\
\mathrm{F} \mathrm{\textrm {cm } ^ { 2 }}\end{array}$ & $\begin{array}{c}\mathbf{R}_{\mathbf{3}} \\
\mathbf{\Omega c m}^{2}\end{array}$ \\
\hline $\begin{array}{l}\text { Uncoated } \\
\text { 316L SS }\end{array}$ & 5644 & 388 & ---- & 0.81 & ---- & ---- & ---- & 190 & $3.933 \times 10^{-5}$ & 534 \\
\hline $600^{\circ} \mathrm{C}$ & 234567 & 32 & $1.36 \times 10-7$ & 0.34 & 537242 & $0.29 \times 10^{-6}$ & 0.28 & 431445 & $0.186 \times 10^{-9}$ & 33842 \\
\hline $800^{\circ} \mathrm{C}$ & 245744 & 28 & $2.71 \times 10-7$ & 0.40 & 546144 & $0.26 \times 10^{-6}$ & 0.37 & 443684 & $0.201 \times 10^{-9}$ & 34562 \\
\hline $900^{\circ} \mathrm{C}$ & 239868 & 35 & $1.11 \times 10-7$ & 0.35 & 531242 & $0.31 \times 10^{-3}$ & 0.31 & 428644 & $0.166 \times 10^{-9}$ & 32982 \\
\hline
\end{tabular}

\subsection{CYCLIC POTENTIODYNAMIC POLARIZATION}

Figure8 shows CPP values of optimized nano YSZ coated 316L SS sintered at different temperature $\left(600,800\right.$ and $\left.900^{\circ} \mathrm{C}\right)$. It is observed that $\mathrm{E}_{\text {corr }}$ values shifted towards less negative direction for the specimen sintered at $800^{\circ} \mathrm{Ccompared}$ to other sintering temperature (Fattah-alhosseini et al., 2011). It is observed that the samples are sintered in air at $800^{\circ} \mathrm{C}$ possess higher corrosion potential $(-129 \mathrm{mV})$ and lower corrosion current density $(0.006$ $\mu \mathrm{A} / \mathrm{cm}^{2}$ ) value compared to samples obtained at other sintering temperatures. Corrosion potential $\left(\mathrm{E}_{\text {corr }}\right)$ and corrosion current density $\left(\mathrm{I}_{\text {corr }}\right)$ are obtained from the polarization curves by Tafel fit and the obtained values are provided in Table 2 . 


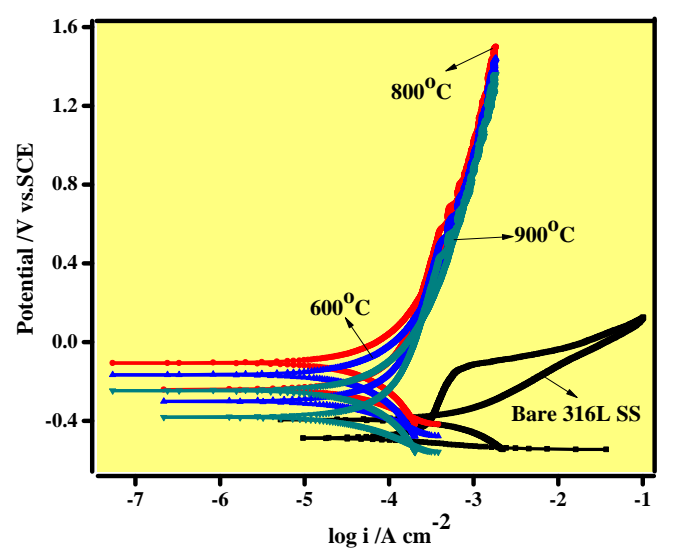

Figure 8 CPP time measurements obtained for optimized nano YSZ coated 316L SS sintered in air at different sintering temperature.

Table 2 Tafel fit values of optimised nano YSZ coated (sintered at 600,800 and $900^{\circ} \mathrm{C}$ under air atmosphere) samples in AS medium comparison with uncoated 316L SS

\begin{tabular}{|c|c|c|}
\hline Sintering Temperature & $\mathbf{E}_{\mathbf{c o r r}}(\mathbf{m V}) \mathbf{v s} \mathbf{S C E}$ & $\mathbf{I}_{\text {corr }} \boldsymbol{\mu} \mathbf{A c m}^{-2}$ \\
\hline $316 \mathrm{~L} \mathrm{SS}$ & -425 & 2.308 \\
\hline $600^{\circ} \mathrm{C}$ & -148 & 0.008 \\
\hline $800^{\circ} \mathrm{C}$ & -129 & 0.006 \\
\hline $900^{\circ} \mathrm{C}$ & -159 & 0.011 \\
\hline
\end{tabular}

\subsection{CELL VIABILITY}

The microscopic images of Cell for control cell line, uncoated and nano YSZ coated 316L SS obtained at $70 \mathrm{~V}$ and 5 minutes after sintering in air at 600,800 and $900^{\circ} \mathrm{C}$ for 1 hour withbar graph are presented in Figure9(a-e).The bar graph at Figure 10 represents the bar graph of cell viability by MTT assay for uncoated and nano YSZ coated 316L SS obtained at $70 \mathrm{~V}$ and 5 minutes after sintering in air at 600,800 and $900^{\circ} \mathrm{C}$ for 1 hour. The cell viability 
for uncoated 316L SS was observed to be about $75.51 \%$. The cell viability for optimized nano YSZ coated $316 \mathrm{~L}$ SS at $70 \mathrm{~V}$ and 5 minutes was observed to be about $83.25 \%, 95.55 \%$ and $80.14 \%$. Hence, the cell viability was more in case of coated samples compared to uncoated metalbecause of its uniform and micro porous coating on the metal surface (Roberge et al.,2000 \& 25].

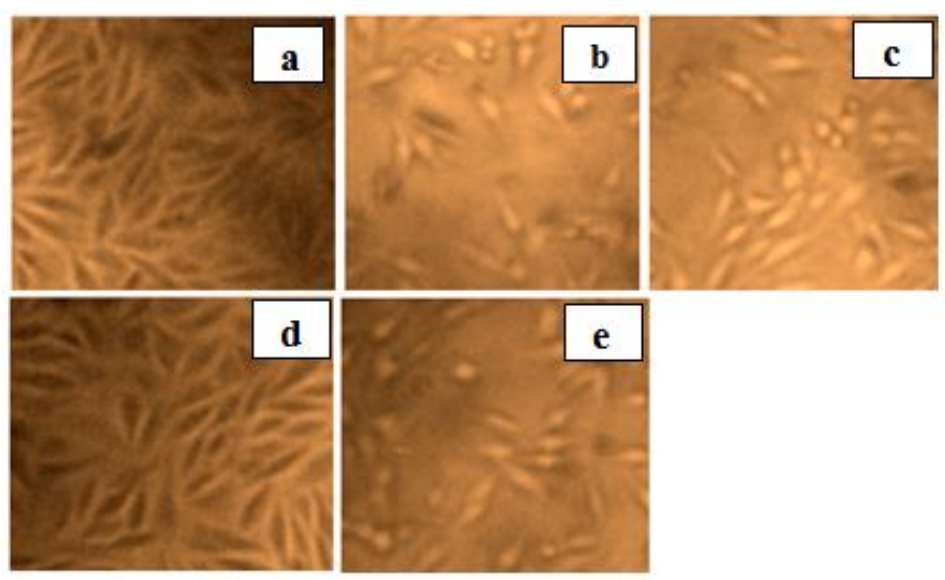

Figure9 (a-c) Microscopic images of Cell for control cell line, uncoated and nano YSZ coated 316L SS obtained at $30 \mathrm{~V}$ and 5 minutes after sintering in air at $800^{\circ} \mathrm{C}$ for 1 hour respectively.

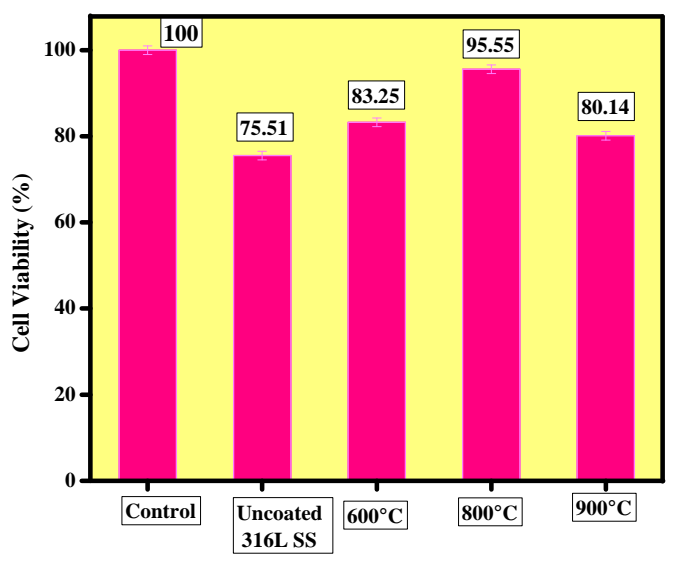

Figure 10 Bar Graph of cell viability by MTT assay for uncoated andnano YSZ coated 316L SS obtained at $30 \mathrm{~V}$ and 5 minutes after sintering in air at $800^{\circ} \mathrm{C}$ for 1 hour. 


\section{CONCLUSION}

Nano porous, uniform tightly packed arrangement of nano YSZ corrosion resistance (in AS medium) of the top layer is important for biomedical applications. These properties are essential for dental implants, which enhance cellular response in terms of adhesion density and proliferation of pre-osteoblasts. The experimental results obtained for optimized nano YSZ coated samples sintered at $800^{\circ}$ Cshowed significant corrosion resistant property. It was observed that as the sintering temperature changes, the same coated layer failed to meet the following properties such as nano porous, uniformity, tightly packed arrangement. Reproducibility is a big challenge and also time consuming. Hence, we have chosen stabilized nano YSZ to coat 316L SS substrate for dental applications.

\section{REFERENCE}

1. Duffo, G., Barreiro, M., Olmedo, D., Crosa., M, Guglielmotti, M.B. \& Cabrini, R.L 1999. An experimental model to study implant corrosion. Acta OdontLatinoamer. 12: 310.

2. Chaturvedi, T.P.2009. An overview of the corrosion aspect of dental implants (titanium and its alloy) Indian J. Dent. Res.20: 91-98.

3. Mouhyi, J., Ehrenfest D.M.D., \& Albrektsson,2012. T. The peri-implantitis: Implant surfaces, microstructure, and physicochemical aspects. Clin. Implant Dent. Relat. Res.14: $170-183$.

4. Danieli, C., Rodrigues, Pilar Valderrama, Thomas, G., Wilson, Jr., Kelli Palmer., Anie Thomas., Sathyanarayanan Sridhar, Arvind Adapalli, Maria Burbano \& Chandur Wadhwani 2013.'Titanium Corrosion Mechanisms in the Oral Environment: A Retrieval Study', Materials.6: 5258-5274. 
5. Mombelli, A., Hashim, D. \& Cionca, N.2018. What is the impact of titanium particles and biocorrosion on implant survival and complications? A critical review. Clin Oral Implants Res. 8(29): 37-53.

6. Anusavice, K.J. 2003. editors, Phillips science of dental materials, Saunders-Elsevier. 11: 56-70.

7. Wataha, J.C. 1996. Materials for endosseous dental implants. J. Oral Rehabil. 23: 79-90.

8. Wennerberg, A. \& Albrektsson, T. 2010. A review of current knowledge and opinions, Int J Oral Maxill of ac Implants. 25: 63-74.

9. Maria Cecilia Corrêa de Sá e Benevides de Moraesa , Carlos Nelson Eliasa , Jamil Duailibi Filhob, Leandra Guimarães de. \& Oliveirab.2004. Mechanical Properties of Alumina-Zirconia Composites for Ceramic Abutments, Materials Research, 7(4): 643649.

10. Denry, I. \& Kelly, J.R 2008. State of the art of Zirconia for dental applications. Dent Mater. 24: 299-307.

11. Je'rôme Chevalier \& Laurent Gremillardw.2009. The Tetragonal-Monoclinic Transformation in Zirconia: Lessons Learned and Future Trends J. Am. Ceram. Soc., 92 (9): 1901-1920.

12. Liu, D., Matinlinna, J.P. \& Pow, EHN 2012, Insights into porcelain Zirconia bonding. J. Adhes. Sci. Technol. 26: 1249-1265.

13. Ossama Saleh Abd El-Ghany , Ashraf Husein Sherief.2016. Zirconia based ceramics, some clinical and biological aspects: Review Future Dental Journal. 2(2): 55-64.

14. AbhishekApratim, PrashantiEachempati, KiranKumar,Krishnappa,Salian, VijendraSingh, Saurabh Chhabra \& Sanket Shah 2015, 'Zirconia in dental implantology: A review', Journal of International society of preventive and community Dentistry. 5:147-156. 
15. Norbert Cionca, Dena Hashim \& Andrea Mombelli. 2017. 'Zirconia dental implants', Periodontology. 73: 241-258.

16. Muthukumaran,V. Selladurai, V., Nandhakumar, S. \& Senthilkumar, M. 2010. Experimental investigation on corrosion and hardness of ion implanted AISI 316L stainless steel. Materials \& Design. 31(6): 2813-2817.

17. Emilija Bajraktarova-Valjakova, Vesna Korunoska-Stevkovska, Biljana Kapusevska, Nikola Gigovski, Cvetanka Bajraktarova-Misevska, \& Anita Grozdanov 2018. Contemporary Dental Ceramic Materials, A Review: Chemical Composition, Physical and Mechanical Properties, Indications for Use. Open Access Macedonian Journal of Medical Sciences, 6(9). 1742-1755.

18. Corni, I, Ryan, M.P. \& Boccaccini, A.R. 2008. Electrophoretic deposition: From traditional ceramics to nanotechnology', J Eur Ceram Soc. 28: 1353-1367.

19. Brandusa Ghiban, Gabriela Jicmon, \& Georgeta Cosmeleata.2006. Structural Investigation Of Electrodeposited Hydroxyapatite On Titanium Supports. 51:187.

20. Sopcak,T., Medvecky,L., Zagyva, T., Dzupon, M., Balko,J. \& Balázsi, K.2018. Characterization and Adhesion Strength of Porous Electrosprayed Polymer-Hydroxyapatite Composite Coatings:3(2):17-23.

21. Callon, G. J., Goldie, D. M., Dibb, M. F., Cairns, J. A. \& Paton, J.2000. X-ray diffraction analysis of Yttria stabilized zirconia powders produced by an organic sol-gel method,Journal of Materials Science Letters:19:1689..

22. Mour, M., Das, D., Winkler, T., Hoenig, E., Mielke, G., Morlock., M. \& Schilling,A.F.2010. Advances in porous biomaterials for dental and orthopaedic applications, Materials.3:2947.

23. Young-Ah Yi, Young-Bum Park, Hyunmin Choi, Keun-Woo Lee, Sun-Jai Kim, Kwang-Mahn Kim, Seunghan Oh, \& June-Sung Shim.2015. The Evaluation of 
osseointegration of dental implant surface with different size of $\mathrm{TiO}_{2}$ nanotube in rats: Journal of Nanomaterials.1-11.

24. Florence Barre, Chantal, M, Van der Valk, Remco, AJ, Dalmeijer, Gert Meijer, Clemens A, van Blitterswijk, Klaas, de Groot \& Pierre Layrolle. 2003. Osteogenecity of octacalcium phosphate coatings applied on porous metal implants', Wiley Periodicals, Inc.1(5): 780-788.

25. Xiaoqiang Xue \& Junfu Lu 2017. Short Communication Electrochemical Impedance Spectroscopy Investigation of a Polyurethane Coating on Bridge 16Mnq Steel Surface, Int. J. Electrochem. Sci.12: 3179 - 3187.

26. Sharif Hussein Sharif Zein \& Muhammad Faiq Abdullah 2012. Electrochemical Impedance Spectroscopy (EIS) Study of Modified Type316L Stainless Steel (SS) as an Effective Biomaterial for Orthopedic Implant Applications, J Nanomed Nanotechol. 3(4): 1-2.

27. Fattah-alhosseini, A., Taheri Shoja, S., Heydari Zebardast, B. \& Mohamadian Samim, P. 2011. Electrochemical Impedance Spectroscopic Study of the Passive State on AISI 304 Stainless Steel, International Journal of Electrochemistry.1-8.

28. Roberge, P.R. 2000. Handbook of Corrosion Engineering. McGraw - Hill Int. Book Co. 723-727.

29. Mosmann.T.1983. Rapid colorimetric assay for cellular growth and survival, Application to proliferation and cytotoxicity assays. Journal of Immunological Methods. 65 1(2): 55-63. 